\title{
Fine-tuning front-line therapy in chronic lymphocytic leukemia
}

\author{
News from ASH 2019
}

\author{
Jan-Paul Bohn (D) - Dominik Wolf
}

Received: 1 April 2020 / Accepted: 28 April 2020 / Published online: 19 May 2020

(C) The Author(s) 2020

\begin{abstract}
Summary A deeper understanding of disease biology and the advent of targeted drugs have implemented chemotherapy-free treatment options in chronic lymphocytic leukemia (CLL). With consistently superior outcome data and good tolerability, the Bruton's kinase inhibitor ibrutinib as well as the B-cell lymphoma 2 inhibitor venetoclax +/- CD20 antibody have recently been licensed for first-line treatment independently of TP53 status and are currently recommended as therapy of choice in most patient subgroups according to international management guidelines. Survival curves, however, have not reached a plateau and relapse due to acquired resistance or drug intolerance remain major hurdles in CLL treatment. Clinical trials currently focus on the most promising combinations and sequences of highly effective targeted drugs aimed at avoiding drug resistance by further enhancing eradication of minimal residual disease and optimizing drug tolerability. This brief review provides an update on the recently presented clinical trial data in first-line CLL at ASH 2019 and discusses clinically relevant obstacles to overcome.
\end{abstract}

Keywords First-line · Ibrutinib · Acalabrutinib . Venetoclax · Obinutuzumab

\section{Introduction}

Novel scientific insights into disease biology have facilitated introduction of targeted therapies to the treatment landscape of chronic lymphocytic leukemia

J.-P. Bohn, MD, PhD ( $\bowtie) \cdot$ Prof. D. Wolf, MD Department of Internal Medicine V, Hematology and Oncology, Medical University of Innsbruck, Anichstraße 35, 6020 Innsbruck, Austria jan-paul.bohn@i-med.ac.at
(CLL). In particular, the Bruton's kinase (BTK) inhibitor ibrutinib and the B-cell lymphoma 2 (BCL2) inhibitor venetoclax $+/-$ CD20 antibody have become front-line treatment of choice in vast parts of the CLL patient spectrum based on consistently superior outcome and tolerability data when compared to chemoimmunotherapy (CIT) [1-4]. Nonetheless, relapse due to acquired resistance and drug intolerance remain major hurdles in patient management [5].

Current clinical trials focus on the most promising sequences and combinations of targeted drugs to prevent resistance formation by enhancing eradication of minimal residual disease (MRD) and optimize drug tolerability. This short review provides an update on currently ongoing first-line clinical trials in CLL presented at ASH (American Society of Hematology) 2019 and discusses clinically relevant obstacles to overcome.

\section{Targeting Bruton's tyrosine kinase}

Aberrant B-cell receptor (BCR) signaling plays a key pathogenetic role in CLL by regulating several pathways essential for B-cell proliferation and apoptosis [6]. BTK functioning downstream of BCR can be selectively targeted and has provided the framework for the striking efficacy seen with the BTK inhibitor ibrutinib in CLL treatment [7].

At ASH 2019 follow-up the ECOG-ACRIN E1219 phase 3 study investigating ibrutinib plus the CD20 antibody rituximab versus CIT with fludarabine, cyclophosphamide and rituximab (FCR) in treatmentnaïve fit CLL patients without deletion 17p was presented and confirmed prolonged progression-free survival (PFS) at 3 years with ibrutinib plus rituximab, including at least equal efficacy even in the subgroup of patients with unmutated immunoglobulin heavychain genes (IGHV). The 3-year overall survival (OS) 
Table 1 Efficacy of targeted drugs in treatment-naive CLL patients in selected randomized controlled clinical trials presented at $\mathrm{ASH} 2019$

\begin{tabular}{|c|c|c|c|c|c|c|c|c|c|c|c|}
\hline Trial & Regimen & $n$ & Agea & ORR & $\mathrm{CR}$ & PR & uMRD & \multicolumn{3}{|l|}{ PFS } & OS \\
\hline \multirow{5}{*}{$\begin{array}{l}\text { ECOG- } \\
\text { ACRIN } \\
\text { E1912 [3, } \\
\text { 8] }\end{array}$} & \multirow{4}{*}{$\begin{array}{l}\text { Ibrutinib } 420 \mathrm{mg} / \mathrm{d} \text {, d1-28, until PD } \\
\text { Rituximab } 50 / 325 \mathrm{mg} / \mathrm{m}^{2} \text {, d1/2, cycle } 2 \\
\text { Rituximab } 500 \mathrm{mg} / \mathrm{m}^{2}, \mathrm{~d} 1 \text {, cycles } 3-7\end{array}$} & \multirow[t]{4}{*}{354} & \multirow[t]{4}{*}{58} & \multirow[t]{4}{*}{$96 \%$} & \multirow[t]{4}{*}{$17 \%$} & \multirow[t]{4}{*}{ NA } & \multirow[t]{4}{*}{$8 \%$} & \multirow{2}{*}{\multicolumn{3}{|c|}{$\begin{array}{l}3 \text { years } \\
89 \%\end{array}$}} & \multirow{4}{*}{$\begin{array}{l}3 \text { years } \\
99 \%\end{array}$} \\
\hline & & & & & & & & & & & \\
\hline & & & & & & & & & UM & M & \\
\hline & & & & & & & & & $\begin{array}{l}89 \% \\
(n=210)\end{array}$ & $\begin{array}{l}88 \% \\
(n=70)\end{array}$ & \\
\hline & $\begin{array}{l}\text { Fludarabine } 25 \mathrm{mg} / \mathrm{m}^{2}, \mathrm{~d} 1-3 \\
\text { Cyclophosphamide } 250 \mathrm{mg} / \mathrm{m}^{2}, \mathrm{~d} 1-3 \\
\text { Rituximab } 50 / 325 \mathrm{mg} / \mathrm{m}^{2}, \mathrm{~d} 1 / 2 \text {, cycle } 1 \\
\text { Rituximab } 500 \mathrm{mg} / \mathrm{m}^{2}, \mathrm{~d} 1 \text {, cycles } 2-6\end{array}$ & 175 & 57 & $81 \%$ & $30 \%$ & NA & $59 \%$ & $71 \%$ & $\begin{array}{l}65 \% \\
(n=71)\end{array}$ & $\begin{array}{l}82 \% \\
(n=44)\end{array}$ & $93 \%$ \\
\hline \multirow{6}{*}{$\begin{array}{l}\text { ELEVATE } \\
\text { TN [11] }\end{array}$} & \multirow{4}{*}{$\begin{array}{l}\text { Acalabrutinib } 100 \mathrm{mg} \text { bid until PD } \\
\text { Obinutuzumab } 1000 \mathrm{mg} \mathrm{d} 1,2,8,15 \\
\text { cycle } 2 \\
\text { Obinutuzumab } 1000 \mathrm{mg} \mathrm{d} 1 \text { cycles } 3-6\end{array}$} & \multirow[t]{4}{*}{179} & \multirow[t]{4}{*}{70} & \multirow[t]{4}{*}{$94 \%$} & \multirow[t]{4}{*}{$13 \%$} & \multirow[t]{4}{*}{$81 \%$} & \multirow[t]{4}{*}{ NA } & \multicolumn{3}{|c|}{ 2-years } & 2-years \\
\hline & & & & & & & & \multirow[t]{3}{*}{$93 \%$} & \multicolumn{2}{|l|}{ IGHV } & \multirow[t]{3}{*}{$95 \%$} \\
\hline & & & & & & & & & UM & M & \\
\hline & & & & & & & & & $\begin{array}{l}89 \% \\
(n=103)\end{array}$ & $\begin{array}{l}96 \% \\
(n=74)\end{array}$ & \\
\hline & Acalabrutinib $100 \mathrm{mg}$ bid until PD & 179 & 70 & $86 \%$ & $1 \%$ & $85 \%$ & NA & $87 \%$ & $\begin{array}{l}87 \% \\
(n=119)\end{array}$ & $\begin{array}{l}83 \% \\
(n=58)\end{array}$ & $94 \%$ \\
\hline & $\begin{array}{l}\text { Chlorambucil } 0.5 \mathrm{mg} / \mathrm{kg} \mathrm{d} 1,15 \text { for } 6 \text { cy- } \\
\text { cles } \\
\text { Obinutuzumab } 1000 \mathrm{mg} \mathrm{d} 1,2,8,15 \\
\text { cycle } 2 \\
\text { Obinutuzumab } 1000 \mathrm{mg} \mathrm{d} 1 \text { cycles } 3-6\end{array}$ & 177 & 71 & $79 \%$ & $5 \%$ & $74 \%$ & NA & $47 \%$ & $\begin{array}{l}33 \% \\
(n=116)\end{array}$ & $\begin{array}{l}76 \% \\
(n=59)\end{array}$ & $90 \%$ \\
\hline \multirow{5}{*}{$\begin{array}{l}\text { CLL14 [4, } \\
26]\end{array}$} & \multirow{4}{*}{$\begin{array}{l}\text { Venetoclax Ramp-up starting d22 of } \\
\text { cycle } 1 \\
\text { Venetoclax } 400 \mathrm{mg} / \mathrm{d} \text { cycles } 3-12 \\
\text { Obinutuzumab } 1000 \mathrm{mg} \mathrm{d} 1,8,15 \\
\text { cycle } 1 \\
\text { Obinutuzumab } 1000 \mathrm{mg} \text { d1 cycles } 2-6\end{array}$} & \multirow[t]{4}{*}{216} & \multirow[t]{4}{*}{72} & \multirow[t]{4}{*}{$85 \%$} & \multirow[t]{4}{*}{$50 \%$} & \multirow[t]{4}{*}{$35 \%$} & \multirow{4}{*}{$\begin{array}{l}76 \% \\
57 \% \\
(\mathrm{BM})\end{array}$} & \multicolumn{3}{|c|}{ 3-years } & 3-years \\
\hline & & & & & & & & \multirow[t]{3}{*}{$82 \%$} & \multicolumn{2}{|l|}{ IGHV } & $87 \%$ \\
\hline & & & & & & & & & UM & M & \\
\hline & & & & & & & & & $\begin{array}{l}\approx 80 \% \\
(n=133)\end{array}$ & $\begin{array}{l}\approx 90 \% \\
(n=83)\end{array}$ & \\
\hline & $\begin{array}{l}\text { Chlorambucil } 0.5 \mathrm{mg} / \mathrm{kg} \mathrm{d} 1,15 \text { for } 12 \text { cy- } \\
\text { cles } \\
\text { Obinutuzumab } 1000 \mathrm{mg} \mathrm{d1}, 8,15 \text { cy- } \\
\text { cle } 1 \\
\text { Obinutuzumab } 1000 \mathrm{mg} \text { d1 cycles } 2-6\end{array}$ & 216 & 71 & $71 \%$ & $23 \%$ & $48 \%$ & $\begin{array}{l}35 \% \\
17 \% \\
(\mathrm{BM})\end{array}$ & $50 \%$ & $\begin{array}{l}\approx 30 \% \\
(n=127)\end{array}$ & $\begin{array}{l}\approx 75 \% \\
(n=86)\end{array}$ & $87 \%$ \\
\hline $\begin{array}{l}\text { ORR over } \\
\text { periphera } \\
M \text { mutate } \\
\text { aMedian, }\end{array}$ & $\begin{array}{l}\text { esponse rate, } C R \text { complete response ra } \\
\text { od, } B M \text { bone-marrow, } P F S \text { progression- } \\
\text { day, bid twice a day, } P D \text { progressive di } \\
\text { s }\end{array}$ & $R p$ & esp & 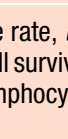 & 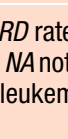 & notion & & & 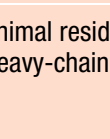 & N. & $\begin{array}{l}\left.J^{-4}\right) \text { in } \\
\text { utated, }\end{array}$ \\
\hline
\end{tabular}

benefit for the experimental study cohort persisted based on very few events (Table 1). Nevertheless, after a median time on treatment of 15.1 months, $21 \%$ of patients $(n=352)$ discontinued ibrutinib for reasons other than disease progression or death, including adverse events (AE) such as arterial hypertension, cardiac events, and arthralgia in $51 \%$ of cases (Table 2). In these patients, median PFS after drug discontinuation was confined to 22.5 months [8].

Facing the relatively high rate of drug discontinuations due to $\mathrm{AE}$, efforts have been made to develop next-generation BTK inhibitors with a more favorable toxicity profile. As many AE with ibrutinib are considered a result of kinase inhibition beyond the BTK, more selective second-generation BTK inhibitors such as acalabrutinib have been developed $[9,10]$.

At ASH 2019 early results of ELEVATE TN, a phase 3 study investigating acalabrutinib alone or in combination with the CD20-antibody obinutuzumab versus chlorambucil and obinutuzumab (GClb) in previously untreated CLL patients were presented. The 2-year
PFS was significantly prolonged with acalabrutinib, a benefit that was consistent across all subgroups, including patients with TP53 dysfunction, deletion $11 \mathrm{q}$ and/or complex karyotype. Of interest, there was a trend towards an additional benefit in overall response rate (ORR) and PFS when acalabrutinib was combined with obinutuzumab (Table 1). The drug discontinuation rate of approximately $20 \%$ due to reasons other than disease progression or death was similar among study arms and mostly due to AE (9-14\%). The most common AE with acalabrutinib were headache, diarrhea, fatigue, and arthralgia (Table 2). A higher incidence of neutropenia (32\% vs. $12 \%)$ as well as high-grade infections, foremost pneumonia $(6.7 \%$ vs. $2.8 \%)$, was reported with the addition of obinutuzumab. Notably, low-grade bleeding events were more frequent with acalabrutinib with/without obinutuzumab compared to GClb (40\% vs. 11\%) [11].

A comparative controlled randomized trial in relapsed high-risk CLL patients is ongoing to help define 
Table 2 Most common adverse events of novel agents in presented phase III studies

\begin{tabular}{|c|c|c|c|}
\hline Clinical trial & E1912 [8] & ELEVATE TN [11] & CLL14 [4] \\
\hline Regimen & $\mathrm{IR}$ & Acala $\pm G$ & VenG \\
\hline \multicolumn{4}{|c|}{ Baseline characteristics } \\
\hline$n$ & 354 & 358 & 216 \\
\hline $\mathrm{Age}^{\mathrm{a}}$ & 57 & 70 & 72 \\
\hline ECOG & $0-2$ & $0-2$ & $0-3$ \\
\hline Follow-up ${ }^{b}$ & 48 & 28 & 28 \\
\hline \multicolumn{4}{|c|}{ Adverse events grade 1-4 } \\
\hline Diarrhea \% & NA & $35-39$ & 28 \\
\hline Nausea \% & NA & $20-22$ & 19 \\
\hline Fatigue \% & NA & $18-28$ & 15 \\
\hline Headache \% & NA & $37-40$ & 11 \\
\hline Bleeding \% & NA & $39-43$ & NA \\
\hline Cough \% & NA & $18-22$ & 16 \\
\hline URTI \% & NA & $18-21$ & NA \\
\hline Arthralgia \% & NA & $16-22$ & NA \\
\hline Neutropenia \% & NA & $11-32$ & 58 \\
\hline Hypertension \% & NA & $5-7$ & NA \\
\hline Atrial fibrillation \% & NA & $3-4$ & NA \\
\hline \multicolumn{4}{|c|}{ Adverse events grade 3-4 } \\
\hline Pneumonia \% & 7 & $32-39$ & 4 \\
\hline Febrile neutropenia & 2 & $1-2$ & 5 \\
\hline Neutropenia \% & 26 & $10-30$ & 53 \\
\hline Anemia \% & 4 & 2 & 8 \\
\hline Thrombocytopenia \% & 3 & NA & 14 \\
\hline Hypertension \% & 9 & $2-3$ & NA \\
\hline Atrial fibrillation \% & 3 & $0-1$ & 0.5 \\
\hline \multicolumn{4}{|c|}{ Drug discontinuations due to adverse events \% } \\
\hline & 14 & $9-11$ & 16 \\
\hline \multicolumn{4}{|c|}{$\begin{array}{l}n \text { number, URTI upper respiratory tract infection, IR Ibrutinib/Rituximab, } \\
\text { Acala Acalabrutinib, G Obinutuzumab, VenG Venetoclax/Obinutuzumab, } \\
N A \text { not available, CLL chronic lymphocytic leukemia } \\
\text { aMedian, years } \\
\text { 'Median, months }\end{array}$} \\
\hline
\end{tabular}

whether acalabrutinib is indeed superior to ibrutinib (NCT02477696).

Despite high ORR and long-term remissions accomplished with BTK inhibition even in genetic highrisk patients, MRD frequently persists and indefinite therapy appears obligatory [12]. The consequence of continuous selection pressure, however, may provoke resistance formation [13]. Indeed, CLL cells of patients progressing under ibrutinib commonly harbor cysteine to serine mutations in BTK at the cysteine 481 residue (C481S) keeping ibrutinib off its binding site or gain-of-function mutations of PLCG2 that reactivate hyperactive BCR signaling. Of interest, these resistance mutations seem to develop early after a median of only 9.4 months on treatment [14].

Although second-generation inhibitors such as acalabrutinib offer more selectivity for BTK than ibrutinib, all of these agents share the same covalent binding site at $\mathrm{C} 481$ and, thus, remain susceptible to resistance formation via C481S mutations [15].

Reversible BTK inhibitors such as LOXO-305 represent a novel class of compounds, which do not require covalent binding to BTK and may be effective regardless of C481S mutations [16]. At ASH 2019 very early results of a phase 1 study investigating LOXO-305 in patients with relapsed B-cell malignancies demonstrated a PR in all 5 CLL patients evaluable for response, including one patient harboring a C481S mutation [17]. At this early stage, however, the role of non-covalent BTK inhibitors in CLL treatment is unclear and remains to be better defined in comparative randomized clinical trials.

\section{Targeting B cell lymphoma 2}

The B cell lymphoma 2 (BCL2) family encompasses pro- and anti-apoptotic proteins, which operate in concert to keep the balance between cell survival and cell death [18]. CLL cells typically evade apoptosis by overexpression of prosurvival protein BCL2 via several mechanisms, including BCL2 repressor deletion as a result of deletion 13q [19, 20]. Venetoclax, a BCL2 inhibitor, causes prompt apoptosis of CLL cells and has proven high ORR and durable remissions in relapsed refractory CLL patients, including those failing BTK inhibition [21, 22]. Although undetectable MRD (uMRD, $<10^{-4}$ ) is frequently observed with venetoclax [23], long-term monotherapy commonly leads to acquired resistance [24]. Similar to ibrutinib, continuous selection pressure is considered to drive clonal evolution towards resistance formation [25].

Recently, venetoclax plus obinutuzumab (VenG) was approved as first chemotherapy-free fixed-duration regimen in first-line treatment by the European Medicines Agency. At ASH 2019, the underlying CLL14 trial, which randomized treatment-naïve CLL patients with comorbidities to VenG or GClb, was updated [4]. With a 40 month follow-up, the PFS advantage for the experimental study arm persisted with survival curves further separating after end of fixed-duration treatment at month six. As seen with other novel compounds in CLL, the PFS benefit is mainly derived from the subgroup of patients with unmutated IGHVstatus with PFS curves splitting in the first 6 months.

Three months after completion of treatment, a remarkably higher rate of UMRD was confirmed for VenG (Table 1). Notably, next-generation sequencing analysis demonstrated uMRD of $<10^{-6}$ in $42 \%$ of patients. Although uMRD appears to remain stable on treatment, MRD kinetics off treatment reveal reoccurrence over time. Nevertheless, uMRD correlates with PFS, as demonstrated by durable remissions in $90 \%$ of uMRD patients with 24 months of follow-up [26].

VenG was generally well tolerated. Table 2 provides an overview of most frequently observed $\mathrm{AE}$. 
Table 3 Efficacy of targeted drugs in treatment-naive CLL patients in selected phase 2 trials presented at ASH 2019

\begin{tabular}{|c|c|c|c|c|c|c|c|c|c|c|c|}
\hline Trial & Regimen & $n$ & $\mathrm{Age}^{\mathrm{a}}$ & ORR & $\mathrm{CR} / \mathrm{CRi}$ & PR & UMRD & PFS & & & OS \\
\hline \multirow{3}{*}{$\begin{array}{l}\text { CAPTIVATE } \\
\text { MRD Cohort } \\
\text { [28] }\end{array}$} & \multirow{3}{*}{$\begin{array}{l}\text { Ibrutinib } 420 \mathrm{mg} / \mathrm{d} \text {, d1-28, cycles } 1-15 \\
\text { Venetoclax Ramp-up starting cycle } 4 \\
\text { Venetoclax } 400 \mathrm{mg} / \mathrm{d} \text { cycles } 4-15\end{array}$} & \multirow[t]{3}{*}{164} & \multirow[t]{3}{*}{58} & \multirow[t]{3}{*}{$100 \%$} & \multirow[t]{3}{*}{ NA } & \multirow[t]{3}{*}{ NA } & \multirow{3}{*}{$\begin{array}{l}74 \% \\
68 \% \\
(\mathrm{BM})\end{array}$} & \multirow[t]{3}{*}{ NA } & \multicolumn{2}{|l|}{ IGHV } & \multirow[t]{3}{*}{ NA } \\
\hline & & & & & & & & & UM & $M$ & \\
\hline & & & & & & & & & $\begin{array}{l}\text { NA } \\
(n=97)\end{array}$ & $\begin{array}{l}\text { NA } \\
(n=67)\end{array}$ & \\
\hline \multirow{4}{*}{$\begin{array}{l}\text { NCT02756897 } \\
\text { [29] }\end{array}$} & \multirow{4}{*}{$\begin{array}{l}\text { Ibrutinib } 420 \mathrm{mg} / \mathrm{d}, \mathrm{d} 1-28 \text {, cycles } 1-27 \\
\text { Venetoclax Ramp-up starting cycle } 4 \\
\text { Venetoclax } 400 \mathrm{mg} / \mathrm{d} \text { cycles } 5-27\end{array}$} & \multirow[t]{4}{*}{80} & \multirow[t]{4}{*}{65} & \multirow[t]{4}{*}{$100 \%$} & \multirow[t]{4}{*}{$96 \%$} & \multirow[t]{4}{*}{$4 \%$} & \multirow{4}{*}{$\begin{array}{l}75 \% \\
\text { (BM) }\end{array}$} & \multicolumn{3}{|l|}{2 years } & \multirow{4}{*}{$\begin{array}{l}2 \text { years } \\
\approx 98 \%\end{array}$} \\
\hline & & & & & & & & $\approx 96 \%$ & IGHV & & \\
\hline & & & & & & & & & UM & $M$ & \\
\hline & & & & & & & & & $\begin{array}{l}\text { NA } \\
(n=63)\end{array}$ & $\begin{array}{l}\text { NA } \\
(n=13)\end{array}$ & \\
\hline \multirow{2}{*}{$\begin{array}{l}\text { NCT02629809 } \\
\text { [31] }\end{array}$} & \multirow[b]{2}{*}{ 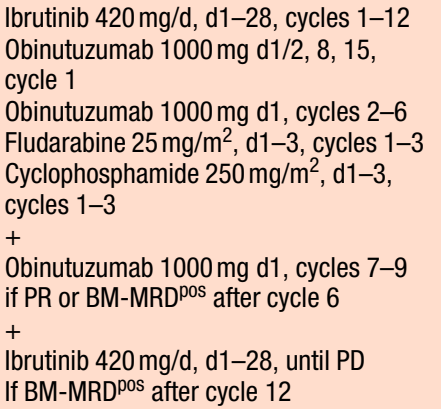 } & \multirow[t]{2}{*}{45} & \multirow[t]{2}{*}{60} & \multirow[t]{2}{*}{$100 \%$} & \multirow[t]{2}{*}{$73 \%$} & \multirow[t]{2}{*}{$35 \%$} & \multirow{2}{*}{$\begin{array}{l}100 \% \\
(\mathrm{BM})\end{array}$} & 3 years & & & 3 years \\
\hline & & & & & & & & $\approx 97 \%$ & & & $\approx 97 \%$ \\
\hline
\end{tabular}

ORR overall response rate, $C R$ complete response rate, $P R$ partial response rate, $U M R D$ rate of patients with undetectable minimal residual disease $\left(<10^{-4}\right)$ in peripheral blood, BM bone marrow, PFS progression-free survival, OS overall survival, NA not available, IGHVimmunoglobulin heavy-chain genes, UM unmutated, $M$ mutated, $d$ day, bid twice a day, $P D$ progressive disease

aMedian, years

\section{Combined inhibition of BTK and BCL2}

A critical mechanism of action of ibrutinib relies on separating CLL cells from their protective microenvironment and, thus, depriving them from essential survival signals [6]. As a result, preclinical data demonstrated increased BCL2 dependence and expression of the anti-apoptotic protein BIM in the remaining CLL cells resulting in increased sensitivity to venetoclax [27].

At ASH 2019 two phase 2 studies investigating fixedduration ibrutinib plus venetoclax followed by MRDguided maintenance in a total of 244 treatment-naïve CLL patients were updated. Treatment schedule encompassed a 3-month induction phase of ibrutinib followed by 12 months of combination therapy in the CAPTIVATE MRD cohort [28] and 24 months in the investigator initiated trial by Jain and coworkers [29], respectively. In all, $90 \%$ of the CAPTIVATE MRD cohort $(n=164)$ completed combination treatment with uMRD in $74 \%$ of patients (Table 3 ). Common grade 3-4 AE included neutropenia (35\%), infections (8\%) and hypertension (7\%) and decreased over time with $39 \%$ of $\mathrm{AE}$ being reported within the first three cycles of combination treatment (Table 4; [28]). In all, $86 \%$ of the patients $(n=80)$ reported by Jain and colleagues completed 24 months of combination therapy and $75 \%$ of them achieved uMRD in the bone marrow (Table 3). Most common grade 3-4 hematologic toxicity was neutropenia seen in $51 \%$ of patients. Besides infections (19\%, foremost pneumonia), atrial flutter/ fibrillation and arterial hypertension were the most frequent non-hematologic grade 3-4 toxicities seen in $10 \%$ of cases each (Table 4 ). One patient died of sudden cardiac death [29]. With a median follow-up of nearly 2 years in both trials, only one patient of the CAPTIVATE MRD cohort has experienced disease progression [28].

\section{The role of chemoimmunotherapy}

CIT has widely faded into the background with novel agents demonstrating superior efficacy and good tolerability in most patient subgroups. FCR has long been treatment of choice for young and fit CLL patients without high-risk genetics achieving MRD negativity and long-term PFS $\geq 10$ years in most cases [30]. Recently, however, the E1912 trial suggested at least comparable outcomes with ibrutinib plus rituximab even in patients with mutated IGHV status.

At ASH 2019, the 30 month follow-up of the phase 2 iFCG trial investigating CIT with fludarabine, cyclophosphamide, and obinutuzumab in combination with ibrutinib (iFCG) in 45 treatment-naïve IGHVmutated CLL patients was presented. Treatment schedule incorporated three cycles of iFCG followed by 9 months of ibrutinib paralleled by MRD-guided courses of obinutuzumab (Table 3). All 41 patients completing 12 months of treatment achieved uMRD in the bone marrow. The most common grade $3-4 \mathrm{AE}$ are summarized in Table 4. Three patients discontinued therapy due to AE including one 26-year-old patient who died of new onset congestive heart failure [31]. 
Table 4 Most common adverse events of novel agents in presented phase II studies

\begin{tabular}{|c|c|c|c|}
\hline Clinical trial & $\begin{array}{l}\text { CAPTIVATE } \\
\text { MRD Cohort [28] }\end{array}$ & NCT02756897 [29] & NCT02629809 [31] \\
\hline Regimen & Ibr-Ven & Ibr-Ven & iFCG \\
\hline \multicolumn{4}{|l|}{ Baseline characteristics } \\
\hline$n$ & 164 & 80 & 45 \\
\hline $\mathrm{Age}^{\mathrm{a}}$ & 58 & 65 & 60 \\
\hline Follow-up ${ }^{b}$ & 15 & 27 & 34 \\
\hline \multicolumn{4}{|c|}{ Adverse events grade $1-4$} \\
\hline Diarrhea \% & 60 & 50 & NA \\
\hline Nausea \% & 35 & 40 & NA \\
\hline Fatigue \% & 21 & 16 & NA \\
\hline Headache \% & 17 & 8 & NA \\
\hline Bleeding \% & NA & 77 & NA \\
\hline Cough \% & NA & NA & NA \\
\hline URTI \% & 25 & NA & NA \\
\hline Arthralgia \% & 20 & 50 & NA \\
\hline Neutropenia \% & 40 & NA & NA \\
\hline Hypertension \% & 12 & 16 & NA \\
\hline Atrial fibrillation \% & NA & 15 & 11 \\
\hline \multicolumn{4}{|c|}{ Adverse events grade 3-4 } \\
\hline Pneumonia \% & NA & $19^{c}$ & 6 \\
\hline Neutropenia \% & 35 & 51 & 58 \\
\hline Febrile neutropenia & 1 & NA & 13 \\
\hline Thrombocytopenia \% & 5 & 2 & 40 \\
\hline Hypertension \% & 7 & 10 & NA \\
\hline Atrial fibrillation \% & 1 & 10 & NA \\
\hline \multicolumn{4}{|c|}{ Drug discontinuations due to adverse events \% } \\
\hline & 5 & 8 & 7 \\
\hline \multicolumn{4}{|c|}{$\begin{array}{l}n \text { number, URT/ upper respiratory tract infection, Ibr-Ven ibrutinib/venetoclax, iFCG ibrutinib, fludarabine, cyclophos- } \\
\text { phamide, obinutuzumab, NA not available } \\
\text { aMedian, years } \\
\text { 'Median, months } \\
\text { 'All infections }\end{array}$} \\
\hline
\end{tabular}

Longer follow-up will help determine whether CIT \pm novel compounds remains an appropriate first-line option for fit patients with low-risk disease.

\section{Conclusion}

The advent of novel compounds has facilitated a paradigm shift in CLL treatment from unspecific DNA damaging agents to targeted therapy. Foremost, BTKand BCL2- inhibitors allow remarkably high ORR and long-term PFS even in genetic high-risk patients.

Indefinite treatment, however, is commonly associated with acquired resistance formation within months unleashing the need to pursue more effective fixed-duration regimens. VenG has recently been approved for front-line therapy as the first chemotherapy-free fixed-duration regimen and has found integration in widely accepted international treatment guidelines.

Clinical trials currently focus on the most promising combinations and sequences of highly effective targeted drugs with unprecedentedly high uMRD rates at convenient drug tolerability possibly inhibiting secondary resistance formation. Longer follow-up will help elucidate whether these combined fixed-duration treatment approaches embrace the ability to ultimately cure CLL in individual patients.

\section{Take home message}

- Targeted therapies have become first-line treatment of choice in most patients with chronic lymphocytic leukemia.

- Indefinite treatment may drive clonal evolution towards resistance formation and hamper drug tolerability.

- Clinical trials currently focus on fixed-duration combinations of highly effective targeted drugs in order to prevent acquired resistance and reduce treatmentrelated toxicity.

Funding Open access funding provided by University of Innsbruck and Medical University of Innsbruck. 
Conflict of interest J.-P. Bohn reports personal fees from AbbVie and Astra-Zeneca for advisory board participation. D. Wolf declares that he has no competing interests.

Open Access This article is licensed under a Creative Commons Attribution 4.0 International License, which permits use, sharing, adaptation, distribution and reproduction in any medium or format, as long as you give appropriate credit to the original author(s) and the source, provide a link to the Creative Commons licence, and indicate if changes were made. The images or other third party material in this article are included in the article's Creative Commons licence, unless indicated otherwise in a credit line to the material. If material is not included in the article's Creative Commons licence and your intended use is not permitted by statutory regulation or exceeds the permitted use, you will need to obtain permission directly from the copyright holder. To view a copy of this licence, visit http://creativecommons.org/licenses/by/4.0/.

\section{References}

1. Woyach JA, Ruppert AS, Heerema NA, Zhao W, Booth AM, Ding W, et al. Ibrutinib regimens versus chemoimmunotherapy in older patients with untreated CLL. N Engl J Med. 2018;379(26):2517-28. https://doi.org/10.1056/ NEJMoa1812836.

2. Moreno C, Greil R, Demirkan F, Tedeschi A, Anz B, Larratt $\mathrm{L}$, et al. Ibrutinib plus obinutuzumab versus chlorambucil plus obinutuzumab in first-line treatment of chronic lymphocytic leukaemia (iLLUMINATE): a multicentre, randomised, open-label, phase 3 trial. Lancet Oncol. 2019;20(1):43-56. https://doi.org/10.1016/S14702045(18)30788-5.

3. Shanafelt TD, Wang XV, Kay NE, Hanson CA, O’Brien S, Barrientos J, et al. Ibrutinib-rituximab or chemoimmunotherapy for chronic lymphocytic leukemia. N Engl J Med. 2019;381(5):432-43. https://doi.org/10.1056/ NEJMoa1817073.

4. Fischer K, Al-Sawaf O, Bahlo J, Fink A-M, Tandon M, Dixon $\mathrm{M}$, et al. Venetoclax and obinutuzumab in patients with CLL and coexisting conditions. N Engl J Med. 2019;380(23):2225-36. https://doi.org/10.1056/ NEJMoa1815281.

5. Strati P, Chaffee K, Achenbach S, Schwager SM, Call TG, KayNE, etal. Disease progression and complications are the main cause of death in patients with chronic lymphocytic leukemia (CLL) independent of age and comorbidities at diagnosis. Blood. 2015;126(23):5265. https://doi.org/10. 1182/blood.V126.23.5265.5265.

6. Hendriks RW, Yuvaraj S, Kil LP. Targeting Bruton's tyrosine kinase in B cell malignancies. Nat Rev Cancer. 2014;14(4):219-32. https://doi.org/10.1038/nrc3702.

7. Herman SEM, Gordon AL, Hertlein E, Ramanunni A, Zhang X, Jaglowski S, et al. Bruton tyrosine kinase represents a promising therapeutic target for treatment of chronic lymphocyticleukemia and is effectively targeted by PCI-32765. Blood. 2011;117(23):6287-96. https://doi.org/ 10.1182/blood-2011-01-328484.

8. ShanafeltTD, Wang V, Kay NE, Hanson CA, O'Brien SM, Barrientos JC, et al. Ibrutinib and rituximab provides superior clinical outcome compared to FCR in younger patients with chronic lymphocytic leukemia (CLL): extended follow-up from the E1912 trial. Blood. 2019;134(Supplement_1):33. https://doi.org/10.1182/blood-2019-126824.

9. BarfT, CoveyT, Izumi R, van de Kar B, Gulrajani M, vanLith B, et al. Acalabrutinib (ACP-196): a covalent bruton tyrosine kinase (BTK) inhibitor with a differentiated selectivity and in vivo potency profile.J Pharmacol Exp Ther. 2017; https:// doi.org/10.1124/jpet.117.242909.

10. Byrd JC, Harrington B, O'Brien S, Jones JA, Schuh A, Devereux S, et al. Acalabrutinib (ACP-196) in relapsed chronic lymphocytic leukemia. N Engl J Med. 2015;374(4):323-32. https://doi.org/10.1056/NEJMoa1509981.

11. Sharman JP, Banerji V, Fogliatto LM, Herishanu Y, Munir T, Walewska R, et al. ELEVATE TN: phase 3 study of acalabrutinib combined with obinutuzumab (O) or alone vs $\mathrm{O}$ plus chlorambucil $(\mathrm{Clb})$ in patients (pts) with treatment-naive chronic lymphocyticleukemia (CLL). Blood. 2019;134(Supplement_1):31. https://doi.org/10. 1182/blood-2019-128404.

12. Ahn IE, Farooqui MZH, Tian X, Valdez J, Sun C, Soto S, et al. Depth and durability of response to ibrutinib in CLL: 5-year follow-up of a phase 2 study. Blood. 2018;131(21):2357-66. https://doi.org/10.1182/blood-2017-12-820910.

13. Landau DA, Sun C, Rosebrock D, Herman SEM, Fein J, Sivina M, et al. The evolutionary landscape of chronic lymphocytic leukemia treated with ibrutinib targeted therapy. Nat Commun. 2017;8(1):2185. https://doi.org/10.1038/ s41467-017-02329-y.

14. Woyach JA, Furman RR, Liu T-M, Ozer HG, Zapatka M, Ruppert AS, et al. Resistance mechanisms for the Bruton's tyrosine kinase inhibitor ibrutinib. N Engl J Med. 2014;370(24):2286-94. https://doi.org/10.1056/ NEJMoa1400029.

15. Byrd JC, Wierda WG, Schuh A, Devereux S, Chaves JM, Brown JR, et al. Acalabrutinib monotherapy in patients with relapsed/refractory chronic lymphocytic leukemia: updated phase 2 results. Blood. 2020;135(15):1204-13. https://doi.org/10.1182/blood.2018884940.

16. Johnson AR, Kohli PB, Katewa A, Gogol E, Belmont LD, Choy R, et al. Battling Btk mutants with noncovalent inhibitors that overcome Cys481 and Thr474 mutations. ACS Chem Biol. 2016;11(10):2897-907. https://doi.org/10. 1021/acschembio.6b00480.

17. Mato AR, Flinn IW, Pagel JM, Brown JR, Cheah CY, Coombs CC, et al. Results from a first-in-human, proofof-concept phase 1 trial in pretreated B-cell malignancies for Loxo-305, a next-generation, highly selective, non-covalent BTK inhibitor. Blood. 2019;134(Supplement_1):501. https://doi.org/10.1182/blood-2019-127509.

18. Vogler M, Walter HS, Dyer MJS. Targeting anti-apoptotic BCL2 family proteins in haematological malignancies-from pathogenesis to treatment. $\mathrm{Br} J$ Haematol. 2017;178(3):364-79. https://doi.org/10.1111/bjh.14684.

19. Cimmino A, Calin GA, Fabbri M, Iorio MV, Ferracin M, Shimizu M, et al. miR-15 and miR-16 induce apoptosis by targeting BCL2. Proc Natl Acad Sci USA. 2005;102(39):13944-9. https://doi.org/10.1073/pnas. 0506654102.

20. Robertson LE, Plunkett W, McConnell K, Keating MJ, McDonnell TJ. Bcl-2 expression in chronic lymphocytic leukemia and its correlation with theinduction of apoptosis and clinical outcome. Leukemia. 1996;10(3):456-9.

21. Souers AJ, Leverson JD, Boghaert ER, Ackler SL, Catron ND, Chen J, et al. ABT-199, a potent and selective BCL-2 inhibitor, achieves antitumor activity while sparing platelets. Nat Med. 2013;19(2):202-8. https://doi.org/10.1038/nm. 3048.

22. Jones JA, Mato AR, Wierda WG, Davids MS, Choi M, Cheson BD, et al. Venetoclax for chronic lymphocytic leukaemia progressing after ibrutinib: an interim analysis of a multicentre, open-label, phase 2 trial. Lancet Oncol. 2018;19(1):65-75. https://doi.org/10.1016/S14702045(17)30909-9. 
23. Wierda WG, Roberts AW, Ghia P, Brown JR, Stilgenbauer S, Cymbalista F, et al. Minimal residual disease status with venetoclax monotherapy is associated with progressionfree survival in chronic lymphocytic leukemia. Blood. 2018;132(Supplement 1):3134. https://doi.org/10.1182/ blood-2018-99-110183.

24. Anderson MA, Tam C, Lew TE, Juneja S, Juneja M, Westerman D, et al. Clinicopathological features and outcomes of progression of CLL on the BCL2 inhibitor venetoclax. Blood. 2017;129(25):3362-70. https://doi.org/10.1182/ blood-2017-01-763003.

25. Herling CD, Abedpour N, Weiss J, Schmitt A, Jachimowicz RD, Merkel O, et al. Clonal dynamics towards the development of venetoclax resistance in chronic lymphocytic leukemia. Nat Commun. 2018;9(1):727. https://doi. org/10.1038/s41467-018-03170-7.

26. Fischer K, Ritgen M, Al-Sawaf O, Robrecht S, Tandon M, Fink A-M, et al. Quantitative analysis of minimal residual disease (MRD) shows high rates of undetectable MRD after fixed-duration chemotherapy-free treatment and serves as surrogate marker for progression-free survival: a prospective analysis of the randomized CLL14 trial. Blood. 2019;134(Supplement_1):36. https://doi.org/10. 1182/blood-2019-125825.

27. Deng J, Isik E, Fernandes SM, Brown JR, Letai A, Davids MS. Bruton's tyrosine kinase inhibition increases BCL-2 dependence and enhances sensitivity to venetoclax in chronic lymphocytic leukemia. Leukemia. 2017;31(10):2075-84. https://doi.org/10.1038/leu.2017.32.

28. Tam CS, Siddiqi T, Allan JN, Kipps TJ, Flinn IW, Kuss BJ, et al. Ibrutinib (Ibr) plus Venetoclax (Ven) for first-line treatment of chronic lymphocytic leukemia (CLL) / small lymphocytic Lymphoma (SLL): Results from theMRD cohort of the phase
2 CAPTIVATE study. Blood. 2019;134(Supplement_1):35. https://doi.org/10.1182/blood-2019-121424.

29. Jain N, Keating MJ, Thompson PA, Ferrajoli A, Burger JA, Borthakur GM, et al. Combined Ibrutinib and Venetoclax for first-line treatment for patients with chronic lymphocytic leukemia (CLL). Blood. 2019;134(Supplement_1):34. https://doi.org/10.1182/blood-2019-131847.

30. Thompson PA, Tam CS, O'Brien SM, Wierda WG, Stingo F, Plunkett W, et al. Fludarabine, cyclophosphamide, and rituximab treatment achieves long-term disease-free survival in IGHV-mutated chronic lymphocytic leukemia. Blood. 2016;127(3):303-9. https://doi.org/10.1182/blood-201509-667675.

31. Jain N, Thompson PA, Burger JA, Ferrajoli A, Takahashi K, EstrovZE, et al. Ibrutinib, Fludarabine, Cyclophosphamide, and Obinutuzumab (iFCG) for first-line treatment of IGHVmutated CLL and without del(17p)/mutated TP53. Blood. 2019;134(Supplement_1):357. https://doi.org/10.1182/ blood-2019-131939.

Publisher's Note Springer Nature remains neutral with regard to jurisdictional claims in published maps and institutional affiliations.

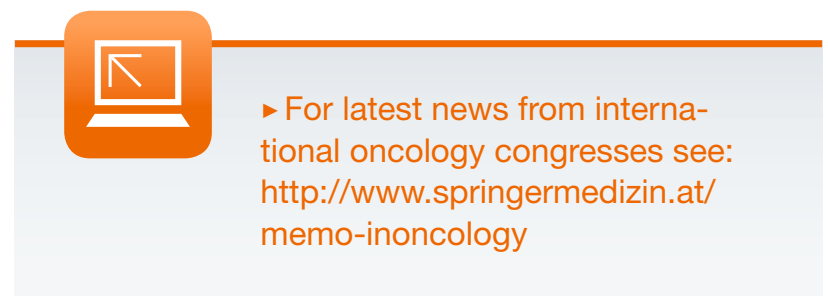

